\title{
PYTANIA TESTOWE
}

\section{Poniżej zamieszczono pytania testowe umożliwiające sprawdzenie wiedzy obejmujące zagadnienia, o których jest mowa w niniejszym numerze „Hematologii”.}

\section{Pytanie 1.}

Do wskazań do rozpoczęcia leczenia u pacjenta z przewleką białaczką limfocytową należą poniższe z wyjatkiem:

A. Stężenia hemoglobiny $(\mathrm{Hb})$ poniżej $10 \mathrm{~g} / \mathrm{dl}$

B. Występowania objawów układowych

C. Limfocytozy ponad $100 \mathrm{G} / \mathrm{L}$ jako izolowanego objawu

D. Objawowego i/lub znacznego, wynoszącego ponad $10 \mathrm{~cm}$, powiększenia węzłów chłonnych

E. Małopłytkowości poniżej $100 \mathrm{G} / \mathrm{L}$

\section{Pytanie 2.}

Wskaż prawdziwe twierdzenia spośród następujących: 1) immunochemioterapia według schematu R-FC (rytuksymab, fludarabina, cyklofosfamid) ma obecnie najsilniejszą rekomendację dla pacjentów poniżej 65. roku życia ze zmutowanym genem dla łańcuchów ciężkich immunoglobulin (IGHV, immunoglobulin heavy chain variable), ponieważ u części tych chorych może doprowadzić do eradykacji minimalnej choroby resztkowej (MRD, minimal residual disease); 2 ) immunochemioterapia według schematu R-FC ma obecnie najsilniejszą rekomendację dla pacjentów powyżej 65. roku życia z niezmutowanym IGHV, ponieważ u części tych chorych może doprowadzić do eradykacji MRD; 3) immunochemioterapia według schematu R-FC ma obecnie najsilniejszą rekomendację dla pacjentów poniżej 65. roku życia ze zmutowanym IGHV, ponieważ u tych chorych jest dobrze tolerowana; 4) do najczęstszych działań niepożądanych wenetoklaksu należą: zespół lizy guza, neutropenia, zakażenia, wysypki i inne zmiany skórne; 5) do najczęstszych działań niepożądanych wenetoklaksu należą: neutropenia, małopłytkowość, biegunki, infekcje dróg oddechowych.
A. Prawdziwe twierdzenia to 1) i 4)
B. Prawdziwe twierdzenia to 3) i 5)
C. Prawdziwe twierdzenia to 2) i 4)
D. Prawdziwe twierdzenia to 1) i 5)
E. Prawdziwe twierdzenia to 2) i 5)

\section{Pytanie 3.}

Wskaż czynniki, które zwiększają prawdopodobieństwo odpowiedzi na erytropoetynę:
A. Duże zapotrzebowanie na transfuzje koncentratu krwinek czerwonych (kkcz)
B. Niskie stężenie endogennej erytropoetyny
C. Wysokie ryzyko według Międzynarodowego Wskaźnika Prognostycznego (IPSS, International Prognostic Scoring System) i Zmodyfikowanego Międzynarodowego Wskaźnika Prognostycznego (IPSS-R, Revised International Prognostic Scoring System)
D. Wysokie stężenie ferrytyny
E. Odsetek blastów w szpiku kostnym przekraczający $10 \%$ 


\section{Pytanie 4.}

Kryteria rozpoznania zespołu mielodysplastycznego (MDS, myelodysplastic syndrome) z obecnością pierścieniowatych syderoblatów to: 1) niedokrwistość; 2) nieobecność blastów we krwi obwodowej; 3) obecność mutacji $S F 3 B 1$ przy odsetku pierścieniowatych syderoblastów w szpiku większym lub równym 15\%; 4) obecność mutacji $S F 3 B 1$ przy odsetku pierścieniowatych syderoblastów w szpiku większym lub równym 5\%; 5) odsetek blastów w szpiku ponad $5 \%$.
A. Kryteriami tymi są: 1), 2) i 4)
B. Kryteriami tymi są: 1), 2) i 3)
C. Kryteriami tymi są: 1), 4) i 5)
D. Kryteriami tymi są: 1), 2) i 5)
E. Kryteriami tymi są: 2), 4) i 5)

\section{Pytanie 5.}

Do czynników ryzyka wznowy po autotransplantacji u chorych $z$ nawrotowąoporną postacią chłoniaka Hodgkina nie należy:
A. Stadium IV choroby przy rozpoznaniu
B. Pierwotna oporność na leczenie pierwszej linii
C. Wznowa choroby do 12 miesięcy po leczeniu pierwszej linii
D. Wznowa o lokalizacji pozawęzłowej
E. Dodatni wynik badania pozytonowej tomografii emisyjnej sprzężonej z badaniem tomografii komputerowej (PET/CT, positron emission tomography/computed tomography) po chemioterapii ratunkowej

\section{Pytanie 6.}

Jacy chorzy z oporną/nawrotową postacią chłoniaka Hodgkina mogą otrzymywać brentuksymab vedotin po autologicznej transplantacji komórek układu krwiotwórczego do sumarycznej liczby 16 cykli? 1) Chorzy nieleczeni brentuksymabem vedotin przed transplantacją o ,wysokim ryzyku wznowy choroby” definiowanym jako pierwotna oporność na leczenie pierwszej linii, wznową choroby przed upływem 12 miesięcy od zakończenia leczenia lub ze wznową choroby z zajęciem narządu pozawęzłowego; 2) chorzy leczeni krótko brentuksymabem vedotin przed transplantacją wykonaną po uzyskaniu odpowiedzi na ten lek, którzy spełniają kryteria „wysokiego ryzyka wznowy choroby”; 3) wszyscy chorzy leczeni krótko brentuksymabem vedotin przed transplantacją wykonaną po uzyskaniu odpowiedzi na ten lek; 4) tylko chorzy bez przeciwwskazań do allogenicznej transplantacji komórek układu krwiotwórczego.
A. Prawdziwe jest tylko twierdzenie 1)
B. Prawdziwe są twierdzenia 1) i 2)
C. Prawdziwe są twierdzenia 1) i 3)
D. Prawdziwe są twierdzenia 1), 2) i 4)
E. Prawdziwe są twierdzenia 1), 3) i 4)

\section{Pytanie 7.}

Wszystkie poniższe twierdzenia dotyczące metabolizmu żelaza są prawdziwe $\underline{z}$ wyjatkiem twierdzenia, że: 1) metabolizm żelaza u zdrowych dorosłych zapewnia równowagę między jego procesami wchłaniania a aktualnym zapotrzebowaniem; 2) patologie przewodu pokarmowego mogą leżeć u podłoża zaburzeń wchłaniania żelaza; 3 ) wchłanianie żelaza $z$ przewodu pokarmowego $\mathrm{w}$ odpowiedzi na jego stężenie w organizmie człowieka jest regulowane przez ekspresję białek jelitowych i wątrobowych; 4) transport żelaza przez łożysko $z$ osocza matki do płodu w trakcie ciąży jest kontrolowany przez hepcydynę płodową; 5) dzienna zalecana dawka żelaza dla kobiet w ciąży to około $27 \mathrm{mg}$.
A. 1)
B. 2)
C. 3)
D. 4)
E. 5) 


\section{Pytanie 8.}

Wskaż prawdziwe twierdzenie dotyczące preparatów żelaza stosowanych $\mathrm{w}$ leczeniu niedokrwistości z niedoboru żelaza: 1) w leczeniu niedokrwistości $\mathrm{z}$ niedoboru żelaza stosuje się żelazo pierwiastkowe w dawce 150-200 mg przez 4 tygodnie; 2) działania niepożądane i nietolerancja preparatów doustnych stanowią istotne wyzwania dla terapii niedokrwistości $z$ niedoboru żelaza; 3) preparaty żelaza podawane parenteralnie stanowią bezpieczną alternatywę dla preparatów doustnych w sytuacji, gdy jest konieczne szybkie uzupełnienie zapasów żelaza w organizmie; 4) preparaty zawierające kompleks wodorotlenku żelaza $\mathrm{z}$ sacharozą charakteryzują się korzystnym profilem bezpieczeństwa w przypadku kobiet $w$ ciąży, a maksymalna tygodniowa dawka nie powinna przekraczać $800 \mathrm{mg}$.
A. Prawdziwe są twierdzenia 1) i 2)
B. Prawdziwe są twierdzenia 1) i 3)
C. Prawdziwe są twierdzenia 2) i 3)
D. Prawdziwe są twierdzenia 1), 2) i 3)
E. Prawdziwe są twierdzenia 2), 3) i 4)

\section{Pytanie 9.}

Do jakiej grupy ryzyka cytogenetyczno-molekularnego według klasyfikacji European LeukemiaNet z 2017 roku należą chorzy o poniższej charakterystyce? Chory 1.: kariotyp prawidłowy, NPM1 ${ }^{\text {mut }}$ FLT3-ITD ${ }^{\text {low }}$ RUNX1; chory 2.: kariotyp prawidłowy, NPM1 ${ }^{w t}$ FLT3-ITD ${ }^{l o w}$; chory 3.: kariotyp prawidłowy, NPM1 ${ }^{\text {mut }}$ FLT3-ITD $^{\text {high }}$ ASXL1; chory 4.: kariotyp złożony, NPM1 ${ }^{\text {wt }}$ FLT3-ITD $^{\text {high }}$ TP53 $^{\text {mu. }}$.

A. Chory 1.: ryzyko korzystne; chory 2.: ryzyko pośrednie; chory $3 .:$ ryzyko pośrednie; chory 4.: ryzyko niekorzystne

B. Chory 1.: ryzyko pośrednie; chory 2.: ryzyko pośrednie; chory 3.: ryzyko niekorzystne; chory 4.: ryzyko niekorzystne

C. Chory 1.: ryzyko korzystne; chory $2 .:$ ryzyko pośrednie; chory 3.: ryzyko niekorzystne; chory 4.: ryzyko niekorzystne

D. Wszyscy opisani chorzy są obciążeni niekorzystnym ryzykiem

E. Żadna z powyższych odpowiedzi nie jest prawidłowa

\section{Pytanie 10.}

Mutację FLT3-ITD wykrywa się u około 50\% chorych na ostrą białaczkę szpikową (AML, acute myeloid leukemia). Obecność mutacji FLT3-ITD ${ }^{\text {high }}$ wiąże się z wyjątkowo niekorzystnym rokowaniem.
A. Oba twierdzenia są fałszywe
B. Pierwsze twierdzenie jest fałszywe, drugie prawdziwe
C. Oba twierdzenia są prawdziwe
D. Pierwsze twierdzenie jest prawdziwe, drugie fałszywe

\section{Pytanie 11.}

U którego z pacjentów należy rozważyć rozpoczęcie leczenia pomalidomidem?

A. U pacjenta $z$ nowo rozpoznanym szpiczakiem plazmocytowym, u którego planuje się przeszczepienie krwiotwórczych komórek macierzystych

B. U pacjenta z nowo rozpoznanym szpiczakiem plazmocytowym, u którego nie jest planowane przeszczepienie krwiotwórczych komórek macierzystych

C. U pacjenta ze szpiczakiem plazmocytowym, u którego stosowano jeden protokół leczenia $z$ talidomidem i wystąpiła po nim polineuropatia obwodowa 3. stopnia

D. U pacjenta ze szpiczakiem plazmocytowym po dwóch liniach leczenia, obejmujących zarówno lenalidomid i bortezomib, u którego w trakcie ostatniego leczenia nastąiła progresja choroby

E. U pacjenta ze szpiczakiem plazmocytowym, u którego stosowano jeden protokół leczenia zawierajacy bortezomib i wystąpiła po nim polineuropatia obwodowa 3. stopnia 
Hematologia 2020, tom 11, nr 4

\section{Pytanie 12.}

\section{Wskaż fałszywe twierdzenie dotyczące terapii pomalidomidem:}

A. Pomalidomid jest wskazany w leczeniu skojarzonym $z$ deksametazonem u dorosłych pacjentów ze szpiczakiem plazmocytowym, u których wystąpiła oporność na lenalidomid

B. Dołączenie do schematu pomalidomid-deksametazon bortezomibu, cyklofosfamidu lub przeciwciał monoklonalnych skutkuje znaczącym wzrostem działań niepożądanych, przy niewielkiej poprawie odsetka odpowiedzi

C. W trakcie terapii pomalidomidem jest wymagane rutynowe monitorowanie parametrów hematologicznych i biochemicznych ze względu na ryzyko powikłań hematologicznych oraz zaburzeń funkcji wątroby

D. Zastosowanie schematu pomalidomid-deksametazon wpływa na wydłużenie przeżycia wolnego od progresji (PFS, progression-free survival), przeżycia całkowitego (OS, overall survival) oraz zwiększenie całkowitego odsetka odpowiedzi (ORR, overall response rate) $\mathrm{w}$ porównaniu ze stosowaniem pomalidomidu w monoterapii

E. Wszystkie powyższe twierdzenia są fałszywe 